\title{
PREVENTING RAPTOR ELECTROCUTIONS IN AN URBAN ENVIRONMENT
}

\author{
Author(s): James F. Dwyer and R. William Mannan \\ Source: Journal of Raptor Research, 41(4):259-267. \\ Published By: The Raptor Research Foundation \\ DOI: http://dx.doi.org/10.3356/0892-1016(2007)41[259:PREIAU]2.0.CO;2 \\ URL: http://www.bioone.org/doi/ \\ full/10.3356/0892-1016\%282007\%2941\%5B259\%3APREIAU\%5D2.0.CO \\ $\% 3 \mathrm{~B} 2$
}

BioOne (www.bioone.org) is a nonprofit, online aggregation of core research in the biological, ecological, and environmental sciences. BioOne provides a sustainable online platform for over 170 journals and books published by nonprofit societies, associations, museums, institutions, and presses.

Your use of this PDF, the BioOne Web site, and all posted and associated content indicates your acceptance of BioOne's Terms of Use, available at www.bioone.org/ page/terms of use.

Usage of BioOne content is strictly limited to personal, educational, and noncommercial use. Commercial inquiries or rights and permissions requests should be directed to the individual publisher as copyright holder. 


\title{
THE JOURNAL OF RAPTOR RESEARGH
}

\section{A QUARTERLY PUBLICATION OF THE RAPTOR RESEARCH FOUNDATION, INC.}

VOL. 41

DECEMBER 2007

No. 4

J. Raptor Res. 41(4):259-267

(C) 2007 The Raptor Research Foundation, Inc.

\section{PREVENTING RAPTOR ELECTROCUTIONS IN AN URBAN ENVIRONMENT}

\author{
JAmes F. DWYer ${ }^{1}$ AND R. William Mannan ${ }^{2}$ \\ School of Natural Resources, University of Arizona, Tucson, AZ 85721 U.S.A.
}

\begin{abstract}
Electrocution of raptors on poles supporting overhead electric lines is a cause of concern in the United States. Techniques for modifying (i.e., retrofitting) potentially lethal poles to reduce electrocutions have been applied in rural areas to poles most likely to be used by raptors. However, raptors also live in urban areas, and criteria for selecting poles to retrofit in towns and cities may differ from those in rural areas. We assessed the effectiveness of using nest sites of Harris's Hawks (Parabuteo unicinctus) in Tucson, Arizona, U.S.A., as a means to focus proactive efforts to retrofit potentially lethal poles. Specifically, we investigated: (1) whether poles close to Harris's Hawk nests were more likely to cause electrocutions than more distant poles with the same configuration; and (2) whether retrofitting poles within $300 \mathrm{~m}$ of nests reduced electrocutions in treated areas. We assessed the number of electrocutions before and after retrofitting by searching for electrocuted hawks at a sample of poles. In 2003, we found 23 electrocuted Harris's Hawks within $300 \mathrm{~m}$ of nests. The proportion of poles that electrocuted a juvenile Harris's Hawk remained relatively constant from 0 to $300 \mathrm{~m}$ from nests. Poles 201-300 m from nests were more likely to electrocute subadult and adult hawks than were poles $<200 \mathrm{~m}$ from nests. Prior to retrofitting poles, we detected 1.4 electrocutions per monitored nest. After about half of the potentially lethal poles within $300 \mathrm{~m}$ of nests were retrofitted, we detected 0.2 electrocutions per nest. For Harris's Hawks in Tucson, risk of electrocution was at least partially related to the proximity of nests to potentially lethal poles. This relationship also may hold for other medium- to large-bodied raptors nesting in urban environments. We recommend that all potentially lethal poles within $300 \mathrm{~m}$ of the nests of urban-nesting raptors be retrofitted through the addition of insulation, or through increased spacing between conductors.
\end{abstract}

KeY WoRDs: Harris's Hawk; Parabuteo unicinctus; electrocution; power poles; retrofitting; urban.

\section{PREVENCIÓN DE ELECTROCUCIÓN DE RAPACES EN UN AMBIENTE URBANO}

RESUMEN.-La electrocución de aves rapaces en los postes que soportan las líneas eléctricas aéreas es una causa de preocupación en los Estados Unidos. En las áreas rurales, se han aplicado técnicas para modificar (i.e., enmendar) los postes potencialmente letales para reducir las electrocuciones en los postes que son usados con mayor probabilidad por las rapaces. Sin embargo, las rapaces también viven en áreas urbanas, y los criterios para seleccionar los postes a enmendar en los pueblos y ciudades pueden diferir de los criterios usados en las áreas rurales. Evaluamos la efectividad de usar los sitios de nidificación de Parabuteo unicinctus en Tucson, Arizona, E.U.A., como un medio para orientar los esfuerzos proactivos de enmendar los postes potencialmente letales. Específicamente, investigamos: (1) si los postes cercanos a los nidos de P. unicinctus presentaron mayor probabilidad de causar electrocuciones que los postes más distantes con la misma configuración; y (2) si los postes enmendados en un radio de $300 \mathrm{~m}$ desde los nidos redujeron las electrocuciones en las áreas tratadas. En una muestra de postes evaluamos el número de electrocuciones antes y después de ser enmendados, mediante búsquedas de individuos de P. unicinctus electrocutados. En 2003,

\footnotetext{
1 Present address: 106 Cheatham Hall, Department of Fisheries and Wildlife Sciences (0321), Virginia Tech, Blacksburg, VA 24061 U.S.A.

2 Email address: mannan@ag.arizona.edu
} 
encontramos 23 individuos electrocutados dentro de los $300 \mathrm{~m}$ alrededor de los nidos. La proporción de postes que electrocutaron a juveniles de $P$. unicinctus permaneció relativamente constante desde 0 a $300 \mathrm{~m}$ desde los nidos. Los postes entre 201 y $300 \mathrm{~m}$ desde los nidos presentaron mayor probabilidad de electrocutar a subadultos y adultos que los postes a menos de $200 \mathrm{~m}$ desde los nidos. Antes de enmendar los postes, detectamos 1.4 electrocuciones por nido monitoreado. Luego de que aproximadamente la mitad de los postes potencialmente letales dentro del radio de $300 \mathrm{~m}$ desde de los nidos fueran enmendados, detectamos 0.2 electrocuciones por nido. Para P. unicinctus en Tucson, el riesgo de electrocución estuvo, al menos parcialmente, relacionado con la proximidad de los nidos a los postes potencialmente letales. Esta relación puede también darse para otras rapaces de tamaño corporal mediano a grande que nidifican en ambientes urbanos. Recomendamos que todos los postes potencialmente letales ubicados hasta $300 \mathrm{~m}$ desde los nidos de rapaces que nidifican en ambientes urbanos sean enmendados utilizando aislantes o incrementando el espacio entre los conductores.

[Traducción del equipo editorial]

Electrocution on poles supporting overhead electric lines (hereafter poles) was recognized as a potentially significant source of mortality for raptors, especially Golden Eagles (Aquila chrysaetos), in the western United States in the early 1970s (Olendorff 1972, Smith and Murphy 1972, Boeker and Nickerson 1975). Subsequently, electrocution was found to be a problem for other raptorial species as well (e.g., Franson and Little 1996, Harness and Wilson 2001, Liguori and Burruss 2003). Since the 1970s, efforts by the Avian Power Line Interaction Committee (APLIC) and others to identify and promote the use of techniques for modifying (i.e., retrofitting) poles with potentially lethal configurations (Miller et al. 1975, Olendorff et al. 1981, APLIC 1996, APLIC 2006) likely has reduced the number of raptors electrocuted in the United States. However, electric shock continues to be identified as a cause of raptor mortality (Manosa 2001, Wayland et al. 2003) and injury (Morrow and Morrow 2003, Dwyer 2006), and the scope and significance of raptor electrocutions remain largely unknown (Bevanger 1998, Lehman 2001, Sergio et al. 2004).

The potential for a pole to electrocute a raptor depends largely on the position of the pole in the environment, the pole-top configuration (Ferrer et al. 1991, Janss and Ferrer 2001, Manosa 2001), and the species, age, and behavior of raptors present (Dawson and Mannan 1994, Janss 2000, APLIC 2006). Retrofitting all poles with potentially lethal pole-top configurations would largely eliminate electrocution as a problem for raptors, but the number of potentially lethal poles combined with time and fiscal constraints, necessitate that electric companies initially identify and retrofit poles most likely to be problematic (Harness 2001, Pearson et al. 2001, Harness and Wilson 2001). Many raptors preferentially hunt and advertise their territories from high perches, and in rural environments, poles overlooking large, open areas (e.g., along ridgelines or agricultural fields) have been found to be the most lethal (Harness and Wilson 2001, Schomburg 2003). However, several species of raptors also nest and are becoming increasingly common in urban environments (Adams 1994, Love and Bird 2000, Millsap et al. 2004). Configurations of pole-tops in urban areas are similar to those in rural environments, but poles often are not situated prominently for aesthetic reasons, and large, open areas may be uncommon. Thus, criteria used in rural areas to identify poles most likely to be lethal to raptors may be suboptimal in towns and cities.

In Tucson, Arizona, U.S.A, several raptor species, including Harris's Hawks (Parabuteo unicinctus), Red-tailed Hawks (Buteo jamaicensis), and Great Horned Owls (Bubo virginianus), are common yearround residents (Mannan et al. 2000) and potentially susceptible to electrocution. Harris's Hawks nest and hunt cooperatively (Mader 1975, Griffin 1976, Whaley 1986, Bednarz 1987a), and in desert environments in southern Arizona, nesting groups, ranging from 2-7 hawks, often consist of a dominant, adult female, two adult males, and offspring from the previous nesting season (Dawson and Mannan 1989, 1991a). The number of nesting groups of Harris's Hawks in Tucson likely has increased from the 1970s to the present (ca. 10 in 1975 [W. Mader pers. comm.]; 46 in 1993 [Dawson and Mannan 1994]; 62 in 2003 [this study]). Electrocution of Harris's Hawks has been reported previously in Tucson (Whaley 1986, Dawson and Mannan 1994), with incidents of electrocution regularly occurring near nests (Dawson and Mannan 1994). These factors led us to form a partnership with Tucson Electric Power Company (TEP), the local electric provider, to assess the effectiveness of using nest sites of Harris's Hawks as a means to focus proactive efforts to retrofit potentially lethal poles. We specifically in- 
vestigated: (1) whether poles close to Harris's Hawk nests in Tucson were more likely to cause electrocutions than were poles with the same configuration further from nests; and (2) whether retrofitting poles within $300 \mathrm{~m}$ of nests reduced the number of electrocutions in treated areas.

\section{STUDY AREA}

In 2004, metropolitan Tucson spanned approximately $1000 \mathrm{~km}^{2}$, supported approximately 900000 people (Population Planning Committee 2004), and included developments ranging from commercial districts and high-density housing to suburban areas with low-density housing. The overhead electric system in Tucson consisted of approximately 111000 poles (J. Sheehey pers. comm.). Tucson is located in the Sonoran Desert and contains remnants of Upper and Lower Sonoran vegetation (Brown et al. 1979), but much of the natural vegetation has been replaced by exotic species or human structures. Rivers and drainage courses are common, but dry most of the year.

\section{METHODS}

From March-September 2003, and February-August 2004, we searched for Harris's Hawk nests where potential nest trees were abundant, where electrocutions had occurred previously, and where information provided by the Arizona Game and Fish Department (AGFD) suggested Harris's Hawks might be found. Because we found more nests than we could monitor effectively, we selected nests for study only if the young from that nest had not yet fledged, and only if there was at least one potentially lethal pole, called a "priority 1 pole," within $100 \mathrm{~m}$ of the nest. We defined a priority 1 pole as having two or more uninsulated, differentially energized conductors closer together than ca. $60 \mathrm{~cm}$, either vertically or horizontally. APLIC (2006) generally recommended $102 \mathrm{~cm}$ of separation to protect non-eagle raptors from electrocution. However, APLIC (2006) also identified the raptor height and the wrist-to-wrist span of a raptor as important dimensions to consider in designing an avian protection plan. Our primary concern was the protection of Harris's Hawks that have heights of 28-43 cm, and wrist-to-wrist spans of ca. $43 \mathrm{~cm}$ (APLIC 2006). Thus, $60 \mathrm{~cm}$ of separation was enough to protect this species, as well as most other raptor species common in the Tucson area. Also, retrofitting differentially energized conductors within $60 \mathrm{~cm}$ typically led to minimum separations between exposed hardware of $>102 \mathrm{~cm}$.

A $300-m$ radius around the nest encompasses the area within which fledgling Harris's Hawks have been reported electrocuted during the first $3 \mathrm{wk}$ after leaving the nest (Dawson and Mannan 1994), and in 2003, after a nest was selected for study, we identified and monitored a sample of poles within this distance. All priority 1 poles within $100 \mathrm{~m}$ of nests were monitored. Each priority 1 pole within $100 \mathrm{~m}$ of each nest was matched to an identically configured pole between 101 and $300 \mathrm{~m}$ from nests. We selected matching poles by generating a random compass bearing for each pole within $100 \mathrm{~m}$ and walking away from the nest along that bearing until we found a matching pole. Occasionally, there were no matching poles beyond $100 \mathrm{~m}$, so we located and monitored an identical pole at another nest already selected for study.

Because we generally found matching poles within $250 \mathrm{~m}$ of nests in 2003, our sample of matching poles between 250 and $300 \mathrm{~m}$ was small. To correct this problem in 2004 , we matched all priority 1 poles $\leq 100 \mathrm{~m}$ from nests to poles in each $100 \mathrm{~m}$ increment from 101 to $500 \mathrm{~m}$. We increased our monitoring radius to $500 \mathrm{~m}$ in 2004 because investigations of reports by Tucson residents of dead raptors led to the discovery of electrocutions occurring beyond $300 \mathrm{~m}$ in 2003. We chose $500 \mathrm{~m}$ because Dawson and Mannan (1991b) found the area $<500 \mathrm{~m}$ from the nest to be the minimum area defended by Harris's Hawks against conspecifics in Arizona. In 2004, we also selected and monitored retrofitted poles as we did priority 1 poles. Retrofitted poles all had differentially energized equipment within $60 \mathrm{~cm}$, but were fitted with insulating materials intended to prevent a raptor from bridging these conductors.

We monitored poles by visiting them once each wk to examine the pole-top with $8 \times 40$ binoculars, and search an area of 7.6-m radius (Harness 2001) around the base of the pole for evidence of electrocuted hawks (i.e., charring on any portion of a dead or injured hawk; Cooper and Eley 1979, Hass 1993, Dawson and Mannan 1994, Burke et al. 2002, Koumbourlis 2002, Dwyer 2006). We collected all carcasses to prevent recounting, and identified them when possible as juvenile (no adult flight feathers present), subadult (some combination juvenile and adult flight feathers present), or adult (no juvenile flight feathers present; Wheeler and Clark 1995), and male or female by mass (females >923 g, males <803 g; Dawson and Mannan $1991 b)$. Poles in nest areas were monitored from the time we confirmed that a nest contained eggs or nestlings until 8 wk after young had fledged. For analyses, poles from all nests were pooled by distance from the nest into $50 \mathrm{~m}$ increments.

We monitored priority 1 poles around nests from April through June 2003. Some breeding groups of Harris's Hawks produce more than one brood per year (Whaley 1986, Bednarz 1987b, Dawson and Mannan 1994), and in July 2003, in response to our preliminary data, TEP began to retrofit priority 1 poles within $300 \mathrm{~m}$ of nests where a second clutch or brood was present. Retrofitting was applied around all nests found in 2004. TEP tried to retrofit all priority 1 poles within $300 \mathrm{~m}$ of all Harris's Hawk nests (J. Sheehey pers. comm.) prior to fledging, but some poles were overlooked. Thus, nest areas in late 2003 and 2004 contained a mixture of retrofitted and priority 1 poles. We used chi-square tests to compare the proportion of priority 1 poles that caused electrocutions relative to distance from nests. We also estimated the number of hawks electrocuted per nest area before and after poles around nests were retrofitted.

Throughout our study, we responded to all reported incidents involving the death or injury of a raptor regardless of whether the reporting party suspected that the animal had been electrocuted. We recorded for every electrocution the species and pole-top configuration involved, and the distance from the incident to the nearest known nest (of the species in question) within $1 \mathrm{~km}$. Residents living within $300 \mathrm{~m}$ of the nests we monitored were notified by letter of our project, and asked to contact us immediately if they encountered a dead or injured raptor. 
Because diagnosing the cause of death from a carcass can be difficult, we report herein only carcasses we observed ourselves. We enhanced our chances of locating electrocuted raptors by coordinating the reporting of incidents with personnel from local governmental and nongovernmental agencies. We also discussed our study at a public meeting of the Tucson Audubon Society, collaborated with the Arizona Daily Star on a newspaper article (Stauffer 2004), held training sessions for electric company personnel, and worked with TEP and the AGFD on an electric bill insert to encourage residents to report raptor nests and mortalities.

We suspected that the carcasses of some electrocuted Harris's Hawks would disappear before being detected on our weekly visits, resulting in underestimation of the full impact of electrocution in monitored areas. We attempted to quantify this loss by placing a raptor carcass at the base of the "safe" pole nearest to a randomly selected sample of 23 nests immediately following our 8-wk monitoring period. Safe poles were defined as poles where all differentially energized conductors were insulated or were separated by $>60 \mathrm{~cm}$. "Safe" is a relative term in this situation, and all poles which do not meet APLIC (2006) standards probably pose some risk to certain species under certain conditions. Raptor carcasses used in this portion of the study were not electrocuted, and were donated by wildlife rehabilitators only after efforts to treat critical injuries had failed.

We visited experimental carcasses daily for $1 \mathrm{wk}$, and every other day for another wk, to determine whether the animals had been moved, and to ascertain what may have moved them. When a resident reported the carcass, we responded by explaining this portion of the project to the resident, and collecting the carcass. To minimize our influence on human responses to carcasses, we placed carcasses near poles before dawn, and observed carcasses through binoculars from a vehicle $>15 \mathrm{~m}$ away for $<1 \mathrm{~min}$. We approached more closely only if the carcass was moved. On each visit, carcasses were recorded as unmoved, moved but still $<7.6 \mathrm{~m}$ from the base of the pole, or moved beyond $7.6 \mathrm{~m}$ (disappeared)

\section{RESULTS}

Monitored Nests. We found 115 Harris Hawk nests during our study (62 in 2003, 53 in 2004) and monitored poles around 58 of them. We omitted 24 nests $(21 \%)$ that had no priority 1 poles within $100 \mathrm{~m}$ (although they did have priority 1 poles within $300 \mathrm{~m}$ ), and 33 nests $(29 \%)$ that were not found until after young had fledged, did not fledge young before the study ended, or failed prior to fledging young. In early 2003, three of 29 firstbrood nests $(10.3 \%)$ with priority 1 poles within $100 \mathrm{~m}$ failed prior to fledging. No monitored second broods failed in 2003. In 2004, four of 30 firstbrood nests $(13.3 \%)$ with priority 1 poles within $100 \mathrm{~m}$ failed prior to fledging. No second broods were monitored in 2004. There was no difference in the probability of failure of monitored first-brood nests in 2003 verses $2004\left(\chi^{2}=0.13\right.$, df $=1, P=$

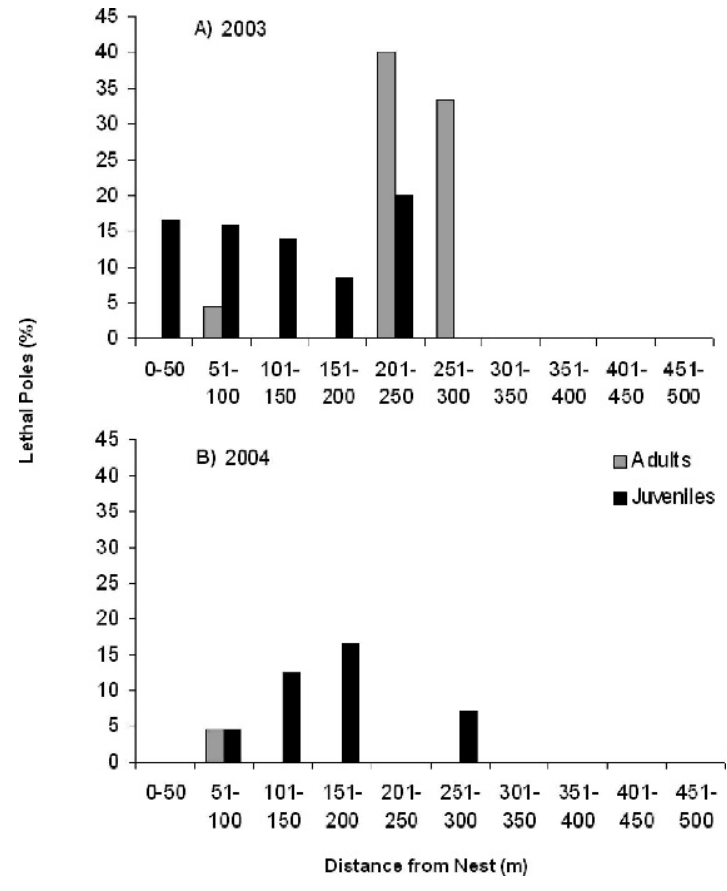

Figure 1. Percent of priority 1 poles within $500 \mathrm{~m}$ of Harris's Hawk nests that electrocuted a Harris's Hawk in Tucson, Arizona, U.S.A., between 1 March and 30 September 2003 (A), and 1 February and 31 August 2004 (B). No poles were monitored beyond $300 \mathrm{~m}$ in 2003. Sample sizes of monitored poles in each increment in 2003 were: 18 from 0-50 m, 44 from $51-100 \mathrm{~m}, 29$ from $101-150 \mathrm{~m}, 24$ from 151-200 m, 5 from 201-250 m, and 6 from 251$300 \mathrm{~m}$. Sample sizes of monitored poles in each increment in 2004 were: 7 from $0-50 \mathrm{~m}, 22$ from $51-100 \mathrm{~m}, 16$ from $101-150 \mathrm{~m}, 12$ from $151-200 \mathrm{~m}, 20$ from $201-250 \mathrm{~m}, 14$ from 251-300 m, 17 from 301-350 m, 26 from 351-400 m, 19 from $401-450 \mathrm{~m}$, and 15 from $451-500 \mathrm{~m}$.

$0.722)$. Thirteen nests monitored in 2003 were also monitored in 2004, and 4 nests monitored in 2004 were within $100 \mathrm{~m}$ of nests monitored in 2003 .

We monitored 126 priority 1 poles around 32 nests in 2003, and 168 priority 1 , and 117 retrofitted poles around 26 nests in 2004. In 2003, we found 23 electrocuted Harris's Hawks within 300 m of nests. The proportion of poles that electrocuted a juvenile Harris's Hawk remained relatively constant up to $300 \mathrm{~m}$ from nests $\left(\chi^{2}=2.04\right.$, df $=5, P=0.843$; Fig. 1). However, poles 201-300 $\mathrm{m}$ from nests were more likely to electrocute subadult and adult hawks than were poles $<200 \mathrm{~m}$ from nests $\left(\chi^{2}=28.0\right.$, $\mathrm{df}=$ $5, P<0.001$; Fig. 1). In 2004, we found only six electrocuted Harris's Hawks around monitored nests, and no relationship between the proportion 
of poles causing electrocution and distance from nest within $500 \mathrm{~m}$ for either juveniles $\left(\chi^{2}=3.38\right.$, $\mathrm{df}=5, P=0.6417)$ or subadult and adult hawks $\left(\chi^{2}\right.$ $=3.17$, $\mathrm{df}=5, P=0.6736)$. Reports by Tucson citizens lead to the detection of four electrocutions beyond $300 \mathrm{~m}$ from nests, but not at monitored nests or on monitored poles in either 2003 or 2004.

The proportion of priority 1 poles within $300 \mathrm{~m}$ of nests that electrocuted a hawk decreased between years from $18.3 \%$ (23 electrocutions/126 poles) in 2003 to $6.6 \%$ (6 electrocutions/91 poles) in 2004 $\left(\chi^{2}=6.24\right.$, df $\left.=1, P=0.013\right)$. Within $100 \mathrm{~m}$ of nests, where we monitored all priority 1 poles in both years, a 56\% reduction (from 18 in 2003 to 7 in 2004) in the number of priority 1 poles (i.e., those retrofitted by TEP), resulted in an $83 \%$ reduction in the number of electrocuted hawks (12 electrocutions in 2003, 2 in 2004). In early 2003, we monitored 26 successful nests (i.e., nests that fledged at least one bird). Prior to retrofitting poles, we found 1.4 electrocutions per nest. This rate was reduced to 0.83 incidents per nest in late 2003 after some poles were modified in anticipation of second broods. In 2004, retrofitting techniques were applied more thoroughly and the number of electrocutions detected declined to 0.2 per nest. None of the Harris's Hawk electrocutions detected at monitored nests caused outages.

We found that some poles presented $>1$ instance of differentially energized hardware within $60 \mathrm{~cm}$. On completely retrofitted poles, each of these instances was identified and insulated. On partially retrofitted poles, at least one of these instances was retrofitted, and at least one was not. Of the 116 completely retrofitted poles we monitored within $500 \mathrm{~m}$ of nests, none electrocuted a Harris's Hawk during our observation period. We also monitored 16 partially retrofitted poles. Of these, one (6.25\%) electrocuted a Harris's Hawk, and one electrocuted a Great Horned Owl.

Mortalities in 2003 and 2004. We found 97 dead Harris's Hawks. At least $77 \%(N=75)$ had been electrocuted (including the 23 within $300 \mathrm{~m}$ of monitored nests). An additional $11 \%(N=11)$ were found in circumstances suggestive of electrocution (e.g., at the base of a priority 1 pole), but had no visible burns. Of the electrocuted Harris's Hawks, $42.7 \%$ were female, $38.6 \%$ were male, and $18.7 \%$ were too decomposed at the time of discovery to be sexed by mass; $61 \%$ were juveniles. We knew the fledging date for 27 of the 46 electrocuted juveniles. Of these, $63 \%$ were killed within 3 wk of fledging.

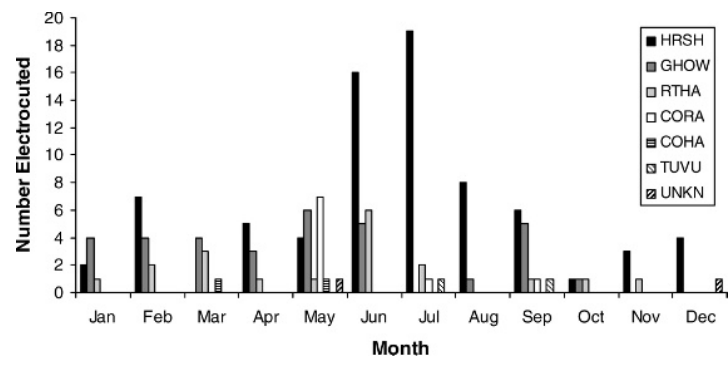

Figure 2. Number of raptors and ravens found electrocuted in Tucson, Arizona, U.S.A., between 1 March 2003 and 31 August 2004 by species and month. HRSH: Harris's Hawk, GHOW: Great Horned Owl, RTHA: Red-tailed Hawk, CORA: Common Raven, COHA: Cooper's Hawk, TUVU: Turkey Vulture, UNKN: species undetermined.

We found 68 other electrocuted birds; 33 Great Horned Owls, 19 Red-tailed Hawks, nine Common Ravens (Corvus corax), two Cooper's Hawks (Accipiter cooperii), two Turkey Vultures (Cathartes aura), one Gila Woodpecker (Melanerpes uropygialis), and two cases of burned raptor feet clamped around energized transformer jumpers for which the species could not be determined. Overall, $84.4 \%$ of the birds we found dead were either confirmed $(N=$ $142)$ or suspected $(N=20)$ of having been electrocuted. We found nests of the respective species within $300 \mathrm{~m}$ of most $(79 \%)$ of these incidents. The number of incidents of electrocution peaked each year with the peak of Harris's Hawk fledging (Fig. 2).

Of the 143 electrocuted birds we documented, 33 were found in 2003, and 110 were found in 2004. None occurred on completely retrofitted poles, and only $4 \%(N=5)$ occurred on partially retrofitted poles. Two of these occurred simultaneously on a single pole, so only four modified poles were found to have electrocuted a raptor during this study. In each of these cases, we aligned burns on the carcass with burns on the pole-top hardware and determined that the incidents occurred at dangerous points omitted during retrofitting. The most common retrofitting mistakes involved failures to recognize that grounded guy wires passed within $60 \mathrm{~cm}$ of energized phase wires, and failures to bring adequate materials to the job so that all potentially lethal sites could be protected during a single visit. In no case did current appear to have passed though, over, or around hardware intended to prevent the electrocution of a raptor.

Lethal Configurations. We detected electrocutions on both distribution (1, 2, and 3 phase) and 
transmission structures, and there was no difference between the construction of the electrical system at this level and the proportion of electrocutions that occurred $\left(\chi^{2}=4.20\right.$, df $=3, P=0.240$; sample sizes are omitted here because the exact numbers of poles of various voltages in the electrical system are proprietary data). When considering only distribution structures, $8 \mathrm{kV}$ portions of the system were significantly more dangerous than the $4 \mathrm{kV}$ portions $\left(\chi^{2}=35.5, \mathrm{df}=1, P \leq 0.0001\right)$. Approximately $25 \%$ of the distribution poles in the study area supported at least one transformer, and transformers were present on $66 \%$ of poles that electrocuted birds. Thus, poles supporting transformers were significantly more likely to electrocute a bird $\left(\chi^{2}=\right.$ 149.8 , df $=1, P \leq 0.0001)$. However, only $10 \%$ of these incidents were found to have occurred on the transformer (as indicated by aligning burns on the bird to burn marks on the electrical equipment), whereas $11 \%$ did not. For the remainder, no evidence could be identified to discern whether the transformer was involved.

Disappearance of Carcasses. We placed 23 carcasses at distances ranging from 7-220 $\mathrm{m}$ from the nest. Of these, six carcasses disappeared within $1 \mathrm{~d}$, and five were reported by residents within $1 \mathrm{~d}$. Two more carcasses disappeared, and two more were reported within $3.5 \mathrm{~d}$. No carcasses were reported after $3.5 \mathrm{~d}$. One more carcass disappeared within $1 \mathrm{wk}$, and another disappeared within $2 \mathrm{wk}$. The remaining six carcasses were never reported or removed (disappearance equation: $\mathrm{Y}=0.729-0.065$ $\ln [\mathrm{d}], \mathrm{r}^{2}=0.93$; where $\mathrm{Y}$ is the proportion of carcasses that remain after exposure days, $\mathrm{d}$; reporting equation: $\left.\mathrm{Y}=0.752-0.026 \ln [\mathrm{d}], \mathrm{r}^{2}=0.65\right)$. These data suggest that we failed to detect one of every three electrocuted Harris's Hawks that died on monitored poles. Residents who reported carcasses often conveyed that they had encountered carcasses in the past and disposed of them with household garbage.

Adding the number of known electrocutions per monitored nest $(N=1.4)$ in 2003 to the projected number of undetected incidents per monitored nest ( $N=0.49$; estimated from the disappearance equation) suggested that in Tucson prior to retrofitting, 1.89 Harris's Hawks were electrocuted annually per nest. In 2003, 62 Harris's Hawk nests were identified. Thus, the estimated annual mortality of Harris's Hawks in Tucson immediately prior to the initiation of proactive retrofitting was 117 birds.

\section{Discussion}

Because we used all nests (successful and unsuccessful) to estimate annual mortality, and searched for Harris's Hawk carcasses around nests adjacent to at least one priority 1 pole, we may have overestimated the importance of electrocution as a mortality factor. However, Harris's Hawk nests with priority 1 poles nearby represented $79 \%$ of the nests we found. We also likely failed to detect all electrocutions at monitored nests because: (1) we did not monitor every pole in the territory; 2) we did not include potentially credible reports of electrocution for which we did not view a carcass; 3) our carcass disappearance project suggests that one of three carcasses disappeared from monitored poles between visits; and (4) we monitored poles for only a few wk each year. Electrocutions of Harris's Hawks were also discovered away from monitored nests, where our efforts to inform residents about electrocution were probably less influential. Also, we likely failed to detect all Harris's Hawk nests in Tucson. Therefore, we suggest that the number of electrocutions reported herein is conservative. Future research should monitor a random sample of nests so that population level effects of electrocution can be assessed.

Fledgling and adult female raptors often are most susceptible to electrocution (Dawson and Mannan 1994, Harmata et al. 2001, Rubinolini et al. 2001), and we found similar trends. We also found that juvenile hawks tended to be electrocuted within $250 \mathrm{~m}$ of nests, whereas adult hawks tended to be killed beyond that radius. We speculate that these patterns reflect behavioral differences. Fledglings tend to stay close to the nest during their initial flights, whereas adults hunt and advertise territoriality farther away. Also, in Harris's Hawks, some group members may be prevented from approaching the nest by dominant individuals (Dawson and Mannan 1991a). High mortality of adult females may be particularly troublesome because growth rates of populations are generally related to rates of survival of breeding females (Caswell 2001). Number of nesting groups of Harris's Hawks in Tucson appears to be increasing, but electrocution may have a negative influence on group size and stability, relative to nesting groups in undeveloped desert (Dawson and Mannan 1994). Further research is needed to resolve whether urban birds are replacing themselves, or whether rural birds are continually being recruited. Also, the residency status (i.e., migratory vs. resident) of birds other than Harris's 
Hawks electrocuted during nonbreeding seasons should be determined.

We detected a disproportionate decrease in number of electrocutions of both adult and juvenile Harris's Hawks around monitored nests relative to the percent of poles retrofitted. Poles missed during retrofitting operations tended to be those that were at least partially hidden behind buildings or large trees. Such obstacles might reduce the awareness or utility of poles to hawks, and thus these poles might be disproportionately underused and less likely to be lethal. It is possible that there were environmental differences between 2003 and 2004 that changed the pattern of movements of hawks around monitored nests, and thus reduced their likelihood of being electrocuted. However, because the number of electrocutions detected tripled throughout the rest of the study area in 2004, this explanation seems unlikely. We do not know what caused the increase in reported electrocutions in 2004, but suspect that it was largely due to an increased awareness of our study by citizens throughout Tucson. We also considered the possibility that the number of electrocutions around monitored nests declined from 2003 to 2004 because many of the most vulnerable birds had already been killed, but dismissed this argument because it implies that electrocutions were not occurring prior to 2003. We know from Whaley (1986), Dawson and Mannan (1994), and the AGFD (unpub. data) that this was not so. We concluded, therefore, that retrofitting poles reduced the number of Harris's Hawks electrocuted near nests in 2004.

For Harris's Hawks in Tucson, electrocutions decreased beyond $300 \mathrm{~m}$ from nests, and we recommend retrofitting all priority 1 poles within $300 \mathrm{~m}$ as soon as nests are identified. Prioritizing poles for retrofitting allows electric utilities to use limited budgets to greatest effect, and if used in other urban areas, this method of prioritizing retrofitting may contribute to protecting other medium- and largebodied birds. This technique may also be used effectively to increase survival of birds nesting in rural areas. However, working only around nests will fail to protect raptors over much of their territories, and will leave resident floaters, and nonresident, nonterritorial migrants vulnerable. Therefore, to more fully protect raptors from the danger posed by overhead power systems, we recommend implementing proactive retrofitting around nests in concert with broader habitat-based risk assessment plans such as those developed by Harness (2001), Schomburg (2003), and
APLIC (2006). Incomplete recognition of all potentially lethal points on some priority 1 poles allowed electrocutions to occur on some retrofitted poles, and forced costly return visits to correct these mistakes. However, no incidents of electrocution occurred on retrofitted portions of modified poles, and retrofitting was highly effective in the short term when installed correctly and completely.

In some cases, raptor protective equipment was installed correctly according to the manufacturer, but did not fit TEP components, and fell off. We emphasize that new materials must be monitored in situ to verify that they function effectively. Those instances where birds were killed on poles or in territories which were only partially retrofitted indicate that when even a single point on a priority 1 pole, or even a single priority 1 pole in a territory remains unprotected, it is likely that a raptor will eventually encounter that site and be electrocuted. We noted raptors perched on or in devices intended to prevent raptors from perching on poles, and do not recommend these devices as a means to reduce electrocution. Very few electrocutions $(<10 \%$; J. Sheehey pers. comm.) could be associated with outages, and raw outage data should not be interpreted as the number of incidents occurring. Our project benefited greatly from our solicitation of information from the public, and we recommend that other investigations involve the public when possible.

Overhead electric systems likely will always be a hazard to raptors, especially during inclement weather when wet feathers and wet equipment increase electrocution risk (APLIC 2006), and it is probably unreasonable to expect that all avian electrocutions will be eliminated as long as overhead power systems exist. However, through modifications to specific portions of the overhead system, and with cooperation between biologists, industry personnel, and the public, the number of raptor electrocutions can be reduced.

\section{ACKNOWLEDGMENTS}

We thank M. Culver and C.J. Conway for technical advice, and S. Archer for lab space. The Arizona Game and Fish Department (AGFD) partially funded this project (Heritage Grant \# U03003), and E. Ostergaard of the AGFD was especially supportive. A Silliman Memorial Research Award also contributed. J. Shin, W. Burroughs, and J. Swift of the Tucson Audubon Society, Pima County Parks and Recreation Department, and Arizona Falconer's Club, respectively, helped us locate nests and electrocution sites. Wildlife rehabilitators L. Bates, D. Bradshaw, J. and L. Miller, and K. Schroeder, and their volunteers alerted us to incidents and cared for injured animals. We are especially 
indebted to the people of Tucson who interrupted their routines to lead us to killed or injured hawks. We also thank S. Foltz, J. Sheehey, and L. Pinnas of TEP for financial and technical support, and for forums to share our findings with utility personnel. Finally, we thank the leadership and line crews of TEP and Southwest Energy Solutions for their ongoing efforts to prevent the electrocution of raptors in their service areas.

\section{Literature Cited}

ADAms, L.W. 1994. Urban wildlife: a landscape perspective. Univ. of Minnesota Press, Minneapolis, MN U.S.A.

Avian Power Line Interaction Committee (APLIC). 1996. Suggested practices for raptor protection on power lines: the state of the art in 1996. Edison Electric Institute and Raptor Research Foundation, Washington, DC U.S.A.

- 2006. Suggested practices for avian protection on power lines: the state of the art in 2006. Edison Electric Institute, APLIC, and the California Energy Commission, Washington, DC and Sacramento, CA U.S.A.

BeDnARZ, J.C. 1987a. Pair and group reproductive success, polyandry, and cooperative breeding in Harris' Hawks. Auk 104:393-404.

- 1987b. Successive nesting and autumnal breeding in Harris' hawks. Auk 104:85-96.

Bevanger, K. 1998. Estimating bird mortality caused by collision and electrocution with power lines: a review of methodology. Pages 29-56 in M. Ferrer and G.F.E. Janss [EDs.], Birds and power lines: collision, electrocution, and breeding. Quercus, Madrid, Spain.

Boeker, E.L. AND P.R. Nickerson. 1975. Raptor electrocutions. Wildl. Soc. Bull. 3:79-81.

Brown, D.E., C.H. Lowe, And C.E. Pase. 1979. A digitized classification system for the biotic communities of North America, with community (series) and association examples for the Southwest. J. Ariz.-Nev. Acad. Sci. 14(1, Supplement).

Burke, H.E., S.E. Swaim, and T. Amalsadyala. 2002. Review of wound management in raptors. J. Avian Med. Surg. 16:180-191.

CASWELl, H. 2001. Matrix population models, 2nd Ed. Sinauer, Sunderland, MA U.S.A.

CoOper, J.E. AND J.T. Eley. 1979. First aid and care of wild birds. David and Charles Inc., North Pomfret, VT U.S.A.

Dawson, J.W. AND R.W. Mannan. 1989. A comparison of two methods of estimating breeding group size in Harris' Hawks. Auk 106:480-483.

— AND - 1991a. Dominance hierarchies and helper contributions in Harris' Hawks. Auk 108:649-660.

- AND - 1991b. The role of territoriality in the social organization of Harris' Hawks. Auk 108:661-672.

— AND —. 1994. The ecology of Harris's Hawks in urban environments. Final report submitted to Arizona Game and Fish Department, Heritage Grant G20058-A, Tucson, AZ U.S.A.

DWYER, J.F. 2006. Electric shock injuries in a Harris's Hawk population. J. Raptor Res. 40:193-199.
Ferrer, M., M. Delariva, and J. Castroviejo. 1991. Electrocution of raptors on power-lines in southwestern Spain. J. Field Ornithol. 62:181-190.

Franson, J.C. AND S.E. LitTle. 1996. Diagnostic findings in 132 Great-horned Owls. J. Raptor Res. 30:1-6.

GRIFFIN, C.R. 1976. A preliminary comparison of Texas and Arizona Harris' Hawks (Parabuteo unicinctus) populations. Raptor Res. 10:50-54.

Harmata, A.R., M. Restani, and G.J. Montopoli. 2001. Movements and mortality of Ferruginous Hawks banded in Montana. J. Field Ornithol. 72:389-398.

HARNESS, R.E. 2001. Effectively retrofitting power lines to reduce raptor mortality. Pages 29-45 in R. Carlton [ED.], [Project Manager], Avian interactions with utility structures: proceedings of the December 1999 workshop. Electrical Power Research Institute, Palo Alto, CA. Charleston, S.C. EPRI Technical Report No. 1006907.

— AND K.R. WILSON. 2001. Electric-utility structures associated with raptor electrocutions in rural areas. Wildl. Soc. Bull. 29:612-623.

HAss, D. 1993. Clinical signs and treatment of large birds injured by electrocution. Pages 180-183 in P.T. Redig, J.E. Cooper, J.D. Remple, and D.B. Hunter [EDS.], Raptor biomedicine. Univ. of Minnesota Press, Minneapolis, MN U.S.A.

JANSS, G.F.E. 2000. Avian mortality from power lines: a morphologic approach of a species specific mortality. Biol. Conserv. 95:353-359.

- AND M. FERRER. 2001. Avian electrocution mortality in relation to pole design and adjacent habitat in Spain. Bird Conserv. Int. 11:3-12.

Koumbourlis, A.C. 2002. Electrical injuries. Critical Care Med. 30 (supplement): S424-S430.

LIGUORI, S. AND J. BuRRUSS. 2003. Raptor electrocution reduction program, 2001-2002 report. Prepared by HawkWatch International for Pacificorp, Salt Lake City, UT U.S.A.

LEHMAN, R.N. 2001. Raptor electrocution on power lines: current issues and outlook. Wildl. Soc. Bull. 29:804-813.

LOVE, O.P. AND D.M. BIRD. 2000. Raptors in urban landscapes: a review and future concerns. Pages 425-434 in R.D. Chancellor and B.-U. Meyburg [EDs.], Raptors at risk: proceedings of the $\mathrm{V}$ world conference on birds of prey and owls. Hancock House and World Working Group on Birds of Prey, Berlin, Germany.

MAdeR, W.J. 1975. Biology of the Harris' Hawk in southern Arizona. Living Bird 14:59-85.

Mannan, R.W., C.W. Boal, W.J. Burroughs, J.W. Dawson, T.S. EstabROOK, AND W.S. RichARDSON. 2000. Nest sites of five raptor species along an urban gradient. Pages 447-453 in R.D. Chancellor and B.-U. Meyburg [EDS.], Raptors at risk: proceedings of the $\mathrm{V}$ world conference on birds of prey and owls. Hancock House and World Working Group on Birds of Prey, Berlin, Germany.

Manosa, S. 2001. Strategies to identify dangerous electricity pylons. Biodivers. Conserv. 10:1997-2012. 
Miller, A.D., E.L. Boeker, R.S. Thorsell, AND R.R. OlenDORFF. 1975. Suggested practices for raptor protection on power lines. Edison Electric Institute, Washington, DC and Raptor Research Foundation, Inc., Provo, UT U.S.A.

Millsap, B., T. Breen, E. McConnell, T. Steffer, L. PhilLiPS, N. Douglass, and S. Taylor. 2004. Comparative fecundity and survival of Bald Eagles fledged from suburban and rural natal areas in Florida. J. Wildl. Manage. 68:1018-1031.

MORROw, J. AND L. MORROw. 2003. Harris' Hawk surviving in the wild after partial loss of wing and one hallux. Bull. Tex. Ornithol. Soc. 36:2-5.

OlendorfF, R.R. 1972. Eagles, sheep and power lines. Colo. Outdoors 21:3-11.

—, A.D. Miller, ANd R.N. Lehman. 1981. Suggested practices for raptor protection on power lines: the state of the art in 1981. Raptor Res. Rep. No. 4. Raptor Research Foundation, Inc., St. Paul, MN U.S.A.

Pearson, D.C., C.G. Thelander, and M. Morrison. 2001. Assessing raptor electrocutions on power lines. Pages 105-124 in R. Carlton [ED.], [Project Manager] Avian interactions with utility structures: proceedings of the December 1999 workshop. Electrical Power Research Institute, Palo Alto, CA. Charleston, S.C. EPRI Technical Report No. 1006907.

Population Planning Committee. 2004. Population estimates and projections. Pima Association of Governments. http://www.pagnet.org/Population/Data/ default.htm (last accessed 8 August 2004).
Rubinolini, D., E. Bassi, G. Bogliani, P. Galeotti, and R. Garavaglia. 2001. Eagle owl (Bubo bubo) and power line interactions in the Italian Alps. Bird Conserv. Int. 11:319-324.

SchomburG, J.W. 2003. Development and evaluation of predictive models for managing Golden Eagle electrocutions. M.S. thesis, Montana State Univ., Bozeman, MT U.S.A.

Sergio, F., L. Marchesi, P. Pedrini, M. Ferrer, and V. PEnTERIANi. 2004. Electrocution alters the distribution and density of a top predator, the eagle owl (Bubo bubo). J. Appl. Ecol. 41:836-845.

Smith, D.G. AND J.R. Murphy. 1972. Unusual causes of raptor mortality. Raptor Res. 6:4-5.

Stauffer, T. 2004. Goal is to stem bird deaths on electrified roosts. Arizona Daily Star. May 3. Archive ID: Merlin_2025951.

Wayland, M., L.K. Wilson, J.E. Elliot, M.J.R. Miller, T. BolLINGER, M. MCAide, K. LANGELIER, J. KEATING, AND J.M.W. FroesE. 2003. Mortality, morbidity, and lead poisoning of eagles in western Canada, 1986-98. J. Raptor Res. 37:8-18.

Whaley, W.H. 1986. Population ecology of the Harris's Hawk in Arizona. Raptor Res. 20:1-15.

WheEler, B.K. AND W.S. Clark. 1995. A photographic guide to North American raptors. Academic Press, San Diego, CA U.S.A.

Received 16 November 2006; accepted 19 July 2007 Associate Editor: Ian G. Warkentin 